\title{
Chronic cardiomyopathy and encephalic spongy changes in sheep experimentally fed Ateleia glazioviana
}

\author{
Miocardiopatia crônica e degeneração esponjosa do encéfalo em ovinos intoxicados experimentalmente \\ por Ateleia glazioviana
}

\author{
Margarida Buss Raffi ${ }^{1}$ Raquel Rubia Rech ${ }^{1}$ Elisa Simone Viegas Sallis ${ }^{1}$ Aline Rodrigues ${ }^{1}$ \\ Claudio Severo Lombardo de Barros ${ }^{2}$
}

\begin{abstract}
Fifteen mature crossbred sheep were fed different daily amounts $\left(2.5-35 \mathrm{~g} \mathrm{~kg}^{-1} \mathrm{bw}\right)$ of the fresh green leaves of Ateleia glazioviana for different periods of time (1-24 days). One sheep was not fed the plant and served as a control. All 16 sheep were euthanatized at different stages of the experiment, necropsied, and several organs, including heart and brain were evaluated histologically. Samples of five brain regions from three affected sheep were evaluated by electron microscopy. Clinical signs observed in three sheep included depression, anorexia, general weakness, staggering gait and prolonged recumbency. One sheep had signs of congestive heart failure. Necropsy findings included subcutaneous dependent edema and edema of the body cavities in two sheep and nutmeg liver in one. Histopathological findings included degeneration, necrosis and interstitial fibrosis in the myocardium of four sheep and vacuolation of cerebral white matter (spongy degeneration, status spongiosus) in 10 sheep, although this latter change were marked only in two of those 10. The ultrastructure of the brain lesion was morphologically consistent with that found in diseases grouped as spongiform myelinopathies in which vacuolation of the myelin occurs in the absence of significant myelin breakdown or phagocytosis. The morphology and pathogenesis of the chronic cardiomyopathy and of the cerebral spongy degeneration in affected sheep in this experiment are discussed and compared with other similar conditions in domestic ruminants.
\end{abstract}

Key words: poisonous plants, Ateleia glazioviana, cardiomyopathy, cerebral spongy degeneration, pathology, sheep diseases.

RESUMO

Quinze ovinos mestiços adultos receberam quantidades variáveis $\left(2,5-35 \mathrm{~g} \mathrm{~kg}^{-1} \mathrm{pv}\right)$, por via oral, das folhas verdes frescas de Ateleia glazioviana durante períodos de tempo que variaram de 1 a 24 dias. Um ovino não recebeu a planta e serviu como controle. Todos os 16 ovinos foram submetidos à eutanásia em diferentes estágios do experimento, necropsiados, e vários órgãos, incluindo coração e encéfalo, foram avaliados histologicamente. Fragmentos de cinco regiões do encéfalo de três ovinos afetados foram avaliados por microscopia eletrônica. Sinais clínicos observados em três ovinos incluíam depressão, anorexia, fraqueza geral, andar vacilante e decúbito prolongado. Um ovino apresentou sinais de insuficiência cardíaca congestiva. Achados de necropsia incluíram edema subcutâneo de declive e das cavidades orgânicas em dois ovinos e fígado de noz-moscada em umdeles. Achados histopatológicos incluíram necrose e fibrose intersticial no miocárdio de quatro ovinos e vacuolização da substância branca (degeneração esponjosa, status spongiosus) em 10 ovinos, embora essa última alteração fosse acentuada em apenas dois ovinos. A ultra-estrutura das lesões encefálicas foi morfologicamente consistente com o que é descrito em um grupo de doenças conhecidas como mielinopatias espongiformes nas quais a vacuolização da mielina ocorre na ausência de degradação significativa da mielina ou fagocitose. A morfologia e patogênese da miocardiopatia crônica e da degeneração esponjosa encefálica nos ovinos deste experimento são discutidas e comparadas com outras condições semelhantes em animais domésticos.

Palavras-chave: plantas tóxicas, Ateleia glazioviana, miocardiopatia, degeneração esponjosa do encéfalo, patologia, doenças de ovinos.

\section{INTRODUCTION}

Ateleia glazioviana (Leg. Papilionoideae) is a native Brazilian tree $5-15 \mathrm{~m}$ in height which is

\footnotetext{
'Programa de Pós-graduação em Medicina Veterinária (PPGMV), área de concentração em Patologia Veterinária, Centro de Ciências Rurais (CCR), Universidade Federal de Santa Maria (UFSM), Santa Maria, RS, Brasil.

${ }^{2}$ Departamento de Patologia, UFSM, 97105-900, Santa Maria, RS, Brasil. E-mail: claudioslbarros@uol.com.br. Autor para correspondência.
} 
commonly found in woods and roadsides and invading pastures in southern Brazil. The plant is palatable and readily consumed by cattle when green herbage is scarce due to long periods of drought or overcrowding; shipping seems to be a predisposing factor to ingestion of the plant (GAVA \& BARROS, 2001).

Heavy losses occur in cattle due to the ingestion of A. glazioviana and three clinical manifestations have been associated with the toxicosis: (i) abortion, (ii) neurological disease characterized by lethargy and occasional blindness, and (iii) heart failure, either acute or chronic. Lesions in the myocardium include degeneration and myocardial fibrosis (GAVA \& BARROS, 2001).

We selected sheep as an experimental animal to reproduce this toxicosis because previous attempts to intoxicate laboratory animals such as rabbits, mice, rats and guinea pigs have failed (LEITE et al., 2002) and also because our first attempts to use sheep as an animal model (STIGGER et al., 2001) indicated that this species is suitable for the study of the pathogenesis of A. glazioviana poisoning in ruminants. The spontaneous intoxication by $\boldsymbol{A}$. glazioviana has now been reported in sheep (GAVA et al., 2003) and the pathogenesis of abortion and other forms of reproductive failure associated with the ingestion of A. glazioviana in sheep were recently determined (RAFFI et al., 2004).

This experiment was conducted to study the morphology and pathogenesis of cardiac and brain lesions induced in sheep by the ingestion of $\boldsymbol{A}$. glazioviana.

\section{MATERIAL AND METHODS}

Data on the experimental design are presented on table 1. Sixteen crossbred adult female sheep with an average weight of $43 \mathrm{~kg}$ were identified by the letters A-P, kept indoors in individual barns of concrete floor and fed alfalfa hay and water ad libitum throughout the experiment. Fifteen of the ewes were fed daily amounts of 2.5 to $35 \mathrm{~g} \mathrm{~kg}^{-1}$ of the fresh green leaves of $\boldsymbol{A}$. glazioviana for different periods of time (1-24 days). One sheep (P) did not receive the plant and served as control. The 15 plant-fed sheep were killed by exanguination after anesthesia with sodium pentobarbitone at different times after the start of the experiment. The control sheep was killed in the same way at the end of the experiment. Necropsy was performed on all 16 sheep. Samples of the heart, brain, lungs, liver and kidneys were fixed in $10 \%$ buffered formalin, dehydrated by standard protocols, embedded in paraffin wax, sectioned at $6 \mathrm{~mm}$, stained with hematoxylin-eosin and evaluated histologically.

Samples of the heart were taken from the septum and from the free borders of right and left ventricles. To provide more controls for the study of myocardial changes, the hearts from eight sheep were collected at an abattoir known to slaughter sheep from regions free of A. glazioviana. These hearts were processed for histology and examined in the same way as the other 16 . The whole brain was fixed in $1.5 \mathrm{~L}$ of $10 \%$ buffered formalin for two weeks and then sectioned coronally at intervals of $0.5 \mathrm{~cm}$ for gross inspection.

Table 1 - Poisoning with Ateleia glazioviana

\begin{tabular}{|c|c|c|c|c|}
\hline Sheep & $\begin{array}{l}\text { Daily amounts of plant fed } \\
\qquad(\mathrm{g} / \mathrm{kg})\end{array}$ & Number of daily feedings & $\begin{array}{l}\text { Total amount of plant fed } \\
\qquad(\mathrm{g} / \mathrm{kg})\end{array}$ & Day of euthanasia \\
\hline A & 30 & 1 & 30 & 12 \\
\hline B & 35 & 1 & 35 & 20 \\
\hline $\mathrm{C}$ & 35 & 1 & 35 & 29 \\
\hline $\mathrm{D}$ & 18 & 2 & 36 & 23 \\
\hline $\mathrm{E}$ & 30 & 2 & 60 & 6 \\
\hline $\mathrm{F}$ & 30 & 2 & 60 & 3 \\
\hline G & 30 & 2 & 60 & 5 \\
\hline $\mathrm{H}$ & 20 & 3 & 60 & 4 \\
\hline I & 10 & 6 & 60 & 23 \\
\hline $\mathrm{J}$ & 5 & 12 & 60 & 40 \\
\hline K & 2.5 & 24 & 60 & 26 \\
\hline $\mathrm{L}$ & 10 & 9 & 90 & 11 \\
\hline M & 5 & 20 & 100 & 22 \\
\hline $\mathrm{N}$ & 10 & 17 & 170 & 18 \\
\hline $\mathrm{O}$ & 10 & 20 & 200 & 37 \\
\hline
\end{tabular}

$(\mathrm{g} / \mathrm{kg})=$ Gram per kilogram of body weight; ${ }^{*}$ Day after the start of the experiment. One sheep $(\mathrm{P})$ did not receive the plant and served as control. All sheep were killed by exanguination after profound anesthesia with sodium pentobarbitone.

Ciência Rural, v.36, n.6, nov-dez, 2006. 
Prior to formalin fixation of the brains of Sheep L, $\mathrm{N}$ and $\mathrm{O}$, samples of $1 \mathrm{~mm}^{3}$ of all the five selected brain areas were placed in $2 \%$ glutaraldehyde in phosphate buffer ( $\mathrm{pH} 7.4$ ) for 2 hours, postfixed in $1 \%$ osmium tetroxide buffered in a $0.4 \mathrm{M}$ sodium cacodylate ( $\mathrm{pH} 7.4)$, dehydrate and embedded in Epon 812. Semithin sections were stained with methylene blue. Ultrathin sections were stained with lead citrate and uranyl acetate and examined with an EM 109 Zeiss electron microscope.

\section{RESULTS}

All sheep were killed 3-40 days after the start of the experiment. Clinical signs were observed only in sheep (J, L-O) that were fed amounts of the plant equal to or greater than $60 \mathrm{~g} \mathrm{~kg}^{-1}$ bw for periods equal to or greater than 9 days. The time of appearance of clinical signs after the start of the experiment range from 4 days to 2 weeks. Clinical signs started as depression and loss of appetite and progressed to weakness, staggering gait and prolonged periods of recumbency. Sheep O presented muffled cardiac sounds, dyspnea, ascites and groaning 7 days before euthanasia. Sheep $\mathrm{J}$ and $\mathrm{L}$ recovered from clinical signs and were clinically normal when euthanatized respectively at 40 and 11 days after the start of the experiment. The clinical signs in sheep M-O remained until they were euthanatized, respectively 22, 18 and 37 days after the start of the experiment with advanced clinical signs.

Gross lesions were observed only at necropsies of Sheep $\mathrm{N}$ and $\mathrm{O}$ and were consistent with congestive (right) heart failure. There were subcutaneous translucent gelatinous dependent edema, hydropericardium (respectively 15 and $55 \mathrm{ml}$ ), hydrothorax (respectively 300 and 1,200ml) and ascites (respectively 2 and 10L). There were firm, irregular white or yellow areas in the myocardium which were more evident on the cut surface of the heart (Figure 1A). The liver of Sheep O was firm, dark red and had a nutmeg aspect on the cut surface.

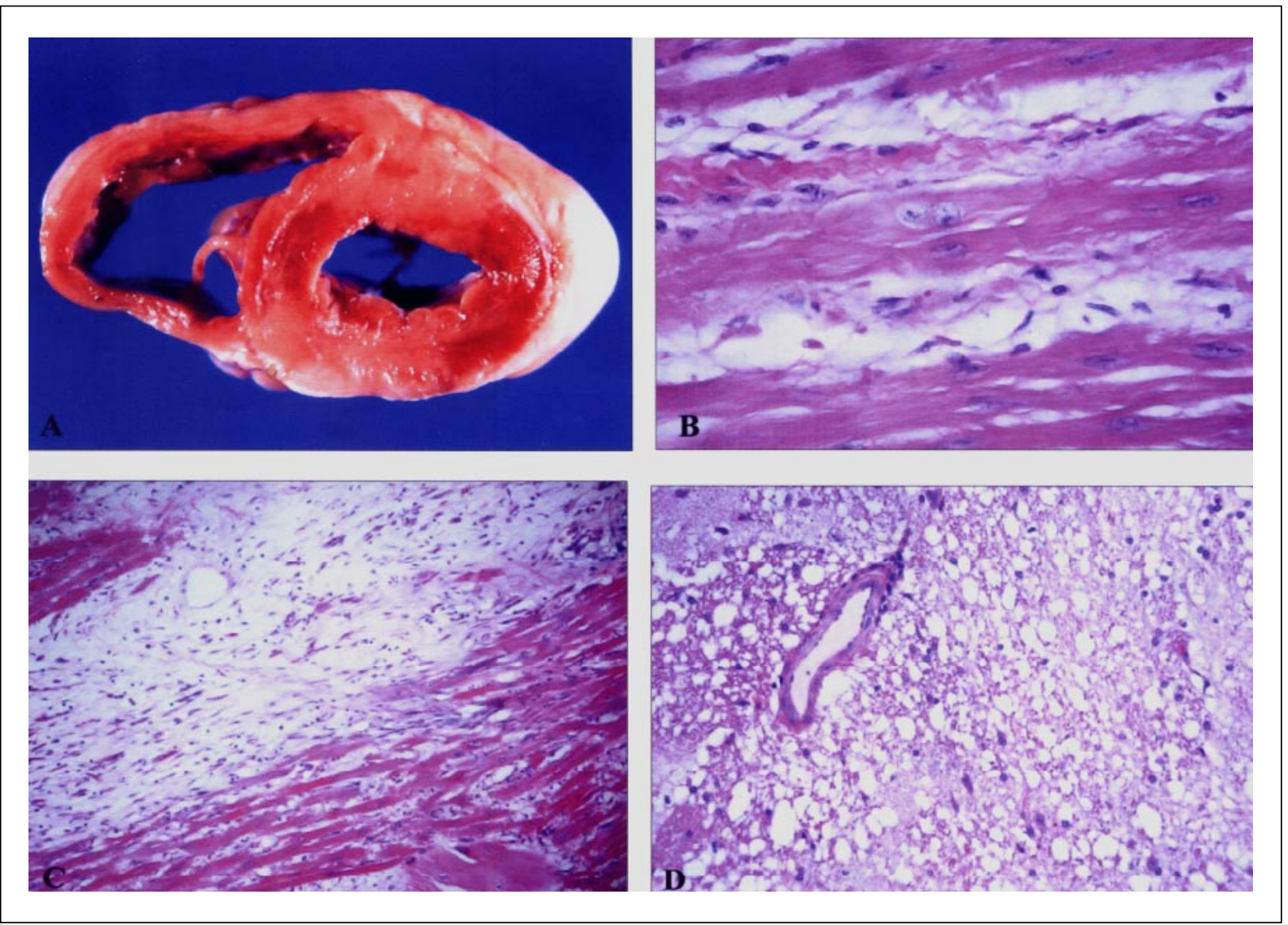

Figure 1 - Pathological changes in sheep experimentally fed Ateleia glazioviana. A. Necropsy findings. The heart is firm and has irregular white or yellow areas on the cut surface (Sheep N). B. Two marked enlarged rond nuclei in close proximity are observed within the same myofiber of the myocardium of Sheep L. HE, obj. 40. C. Histopathology. Large areas of fibrosis in the myocardium of Sheep N. (Hematoxilin and eosina [HE], obj. 10). D. Marked vacuolation of the telencephalic subcortical white matter at the level of the parietal lobe of Sheep O. HE, obj. 20

Ciência Rural, v.36, n.6, nov-dez, 2006. 
Other than the centrilobular congestion, hepatocellular fatty degeneration and necrosis, (secondary lesion to heart failure) observed in the liver of Sheep O, histopathological changes were restricted to the heart and brain.

Histopathological changes observed in the myocardium will be presented in two groups: (i) those occurring only in sheep that were fed A. glazioviana $(n=15)$ and (ii) those found both in the hearts of experimental sheep receiving the toxic plant and in the control hearts $(n=24)$.

Lesions observed exclusively in the myocardium of sheep fed A. glazioviana were observed only in four sheep (I, L, N, O). Early lesions in this group were characterized by swelling of myofibers with finely granular sarcoplasm, loss of cross striations and paleness (rarefaction of myofibrils) in the perinuclear region. The nuclei of affected cardiac myofibers were 2-3 times the size of those observed in the nuclei of control hearts and were vesicular, round, oval or elongated, occasionally with indentations which conferred a convoluted aspect to the nuclear membrane. Frequently two or more nuclei could be seen in close proximity in the same myofiber (Figure 1B).

In more advanced lesions there was partial or complete loss of cytoplasm, with only the collapsed basal laminae remaining in the middle of a condensed interstitial stroma. Subsequently large areas of fibrosis replaced large groups of lost cardiac myofibers (Figure 1C). In Sheep $\mathrm{N}$ and $\mathrm{O}$ there was marked hyaline necrosis with mineralization of cardiac myofibers. Some of these fibers were infiltrated by inflammatory cells and abortive fiber regeneration associated with multinucleated giant cells was occasionally observed. The degree of intensity and distribution of these lesions in the 4 affected sheep were similar.

Histological changes observed equally in the hearts of plant fed sheep as in the hearts of control sheep consisted of eosinophilia of sarcoplasm and nuclear pyknosis; these changes could be seen in isolated fibers or as clusters of degenerate fibers which were occasionally associated with a mild to moderate mononuclear inflammatory infiltrate and fragments of necrotic fibers (floccular necrosis). Sarcocystis sp. were found in all sections of myocardium examined; they appeared in the sarcoplasm of cardiac myofibers, within Purkinje fibers and, occasionally, within the cytoplasm of endothelial cells. Cysts were $20-200 \mathrm{~mm}$ in diameter and contained numerous 4-8mm, basophilic, elliptical or banana-shaped tachyzoites. Frequently the protozoa were associated with clusters of degenerate, necrotic fibers and inflammatory infiltrate.
No lesions were found in the brain of Sheep A-C, F, H or in the control sheep. Lesions found in Sheep D-K and $\mathrm{M}$ were either mild or minimal. Brain lesions were moderate to severe in Sheep L, N and O. The main histopathological changes found in the brain of affected sheep was widespread spongy degeneration (status spongiosus) which varied from mild to severe. Lesions were symmetrical and most conspicous, in decreasing order of frequency, in the telencephalic subcortical white matter adjacent to lateral ventricles, in the mesencephalon at the level of rostral colliculi, in the peripheral white matter of thalamus, in the white matter of cerebellar peduncles and pons, in the white matter of cerebellar medullae and in the internal capsule interposed between the basal ganglia. No spongy degeneration was found in the medulla oblongata. The vacuoles in the neuropil were round to oval or elongated, uni- or multilocular, and 5-40mm in diameter (Figure 1D). Coalescence of vacuoles was frequent. In sheep with mild spongy change only a few small vacuoles were seen in the white matter of thalamic optic tracts. There was no evidence of either axonal or myelin degeneration nor of inflammation. The severity of spongy degeneration in the brain of affected sheep occurred in decreasing order of intensity in the mesencephalon, parietal cortex, thalamus, cerebellum, cerebellar peduncles and basal ganglia.

The ultrastructure of these vacuoles consisted of empty spaces located in the outer portions of myelin sheaths (Figure 2A). These empty spaces were formed by the splitting of myelin sheaths at the intraperiod lines (Figure 2B). The empty spaces were surrounded by few myelin lamellae. Extracellular spaces were dilated.

\section{DISCUSSION}

In this experiment the clinical signs induced in sheep by the feeding of Ateleia glazioviana were characterized by chronic congestive heart failure and neurological disturbances. Pathological lesions consisted of chronic degenerative cardiomyopathy and spongy degeneration of the white matter of the brain. These lesions are remarkably similar to those found in cattle (GAVA \& BARROS, 2001) and sheep (GAVA et al., 2003) with naturally occurring intoxication with $\boldsymbol{A}$. glazioviana.

Clinical signs were observed only in five sheep of this experiment and were confined to those fed large total amounts equal to or greater than $60 \mathrm{~g} \mathrm{~kg}^{-1} \mathrm{bw}$ of the plant for 9 or more days. Large single doses can cause abortion in pregnant sheep (RAFFI et al. 2004) or neurological signs (STIGGER et al., 2001), but it seems 


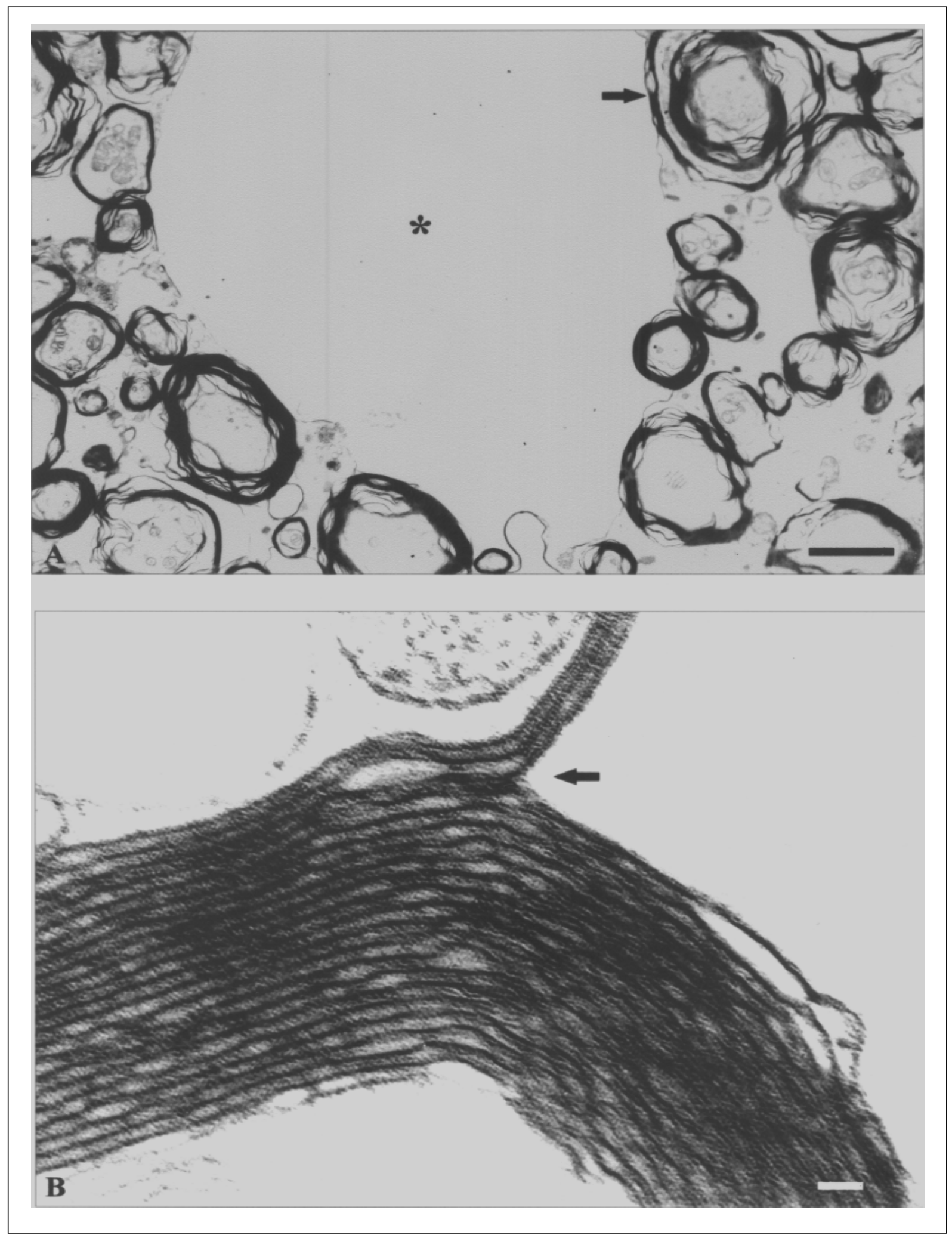

Figure 2 - Transmission electron microscopy of the cerebrum in sheep experimentally fed Ateleie glazioviana. A. intramyelinic vacuolation (arrow) and distension of extracellular space (asterisk). Bar $=10 \mathrm{~nm}$. B. higher magnification of the previous lesion illustrates splitting of myelin lamella at the intraperiod line (arrow). Bar $=5 \mathrm{~nm}$.

Ciência Rural, v.36, n.6, nov-dez, 2006. 
that if the feeding is discontinued remission of the neurological signs occurs. Myocardial lesions occurred only in sheep fed smaller amounts of the plant $\left(10 \mathrm{~g} \mathrm{~kg}^{-1}\right)$ for 6-20 days totalling $60-200 \mathrm{~g} \mathrm{~kg}^{-1}$ bw of $\boldsymbol{A}$. glazioviana. Considering the data of this and of other experiments (STIGGER et al., 2001) with A. glazioviana in sheep and also considering observations on the spontaneous disease in cattle (GAVA \& BARROS, 2001) it is apparent that ruminants which consume large amounts of A. glazioviana for short periods of time develop the neurological form of the disease which can be fatal, but which, if the ingestion is discontinued, are potentially reversible. Smaller amounts ingested for longer periods of time induce chronic cardiomyopathy and heart failure which is eventually fatal.

Two sheep in this experiment had clinical signs of heart failure. The gross myocardial lesions related to the administration of $\boldsymbol{A}$. glazioviana to sheep in this experiment consisted of pale and firm areas in the myocardium. In the light microscopic examination, these pale areas corresponded to degenerate/necrotic, occasionally mineralized myocardial fibers and interstitial fibrosis. The intensity of myocardial lesion was the same in all those regions of the heart examined, unlike that reported by others (STIGGER et al., 2001) who doccumented more severe lesions in the left ventricle and atria. It seems that the first change observed in the myocardium by light microscopy is swelling of the myofiber and an associated loss of eosinophilia (paleness) around nuclei of myocardial fibers. Our observations based on light microscopic examination suggest the following sequence of events: swelling of the myocardial fibers progresses to destruction of the sarcoplasm turning the myofiber in to an empty tube limited only by the sarcolemma which eventually collapses. When the myocardium is histologically examined at this stage, one can observe multifocal pale areas (less eosinophilic) which correspond to areas of fiber loss and passive fibrosis. As time goes by, fibrosis may dominate the histological picture. Hyaline and floccular necrosis of cardiac myofibers were observed frequently in our cases. These changes were occasionally associated with inflammatory events and abortive attemps at regeneration (invasion of the sarcolemmal tube by inflammatory cells, appearance of multinucleated giant cells). It was not possible to determine whether these lesions represented advanced stages of the previously described events or whether they were independent.

The early myocardial lesions in sheep experimentally fed $\boldsymbol{A}$. glazioviana are compatible with changes described as colliquative myocytolysis (ROBINSON \& MAXIE, 1993) and the ultrastructural aspects of these lesions are referred to as myofibrillar degeneration (STIGGER et al., 2001). However these changes are non-specific and may be caused by several agents. In cases of degeneration/necrosis of the myocardium there have been attempts to relate certain responses of myofibers to the injury from different agents, but a conclusive association of this kind remains elusive (ROBINSON \& MAXIE, 1993).

The gross and microscopic lesions observed in the myocardium of sheep from our study are qualitatively the same as those described in several spontaneously occurring toxic cardiomyopathies induced in domestic ruminants by the ingestion of plants such as A. glazioviana (GAVA \& BARROS, 2001), Tetrapterys acutifolia and T. multiglandulosa (PEIXOTO et al., 1995), Pachystigma pygmaeum, $\boldsymbol{P}$. thamnus, Pavetta harborii, P. schumaniana and Fadogia monticola (KELLERMAN et al., 1988).

Some of the histopathological changes observed in the myocardium of sheep from this experiment occurred both in plant-fed sheep and in controls. A secure knowledge of these non-specific incidental lesions and histological artifacts to which the myocardium is prone is essential for the recognition of true and significant myocardial lesions.

Neurological signs were observed in 3 sheep fed A. glazioviana. These included depression, loss of appetite, weakness, staggering gait and prolonged periods of recumbency. Similar signs have been described in spontaneous and experimental poisoning by A. glazioviana in cattle (GAVA \& BARROS, 2001) and in sheep (STIGGER et al., 2001; GAVA et al., 2003) and have been atributted to spongy degeneration (status spongiosus) of the white matter of the brain and it has been suggested that this lesion is potentially reversible (GAVA \& BARROS, 2001). Histological lesions of spongy degeneration were observed in the brains of 10 of 15 sheep fed A. glazioviana. Spongy degeneration results from vacuolation within processes of the neuropil, vesiculation of myelin sheaths or swelling of astrocytes or oligodendrocytes (VAN DER LUGT, 2002). The specific morphological basis for the spongy change can only be determined by electron microscopy. Most of the time the spongy changes result from intramyelinic vacuolation caused by splitting of myelin lamellae along the intraperiod line producing empty vacuoles lined by myelin lamellae (Van der Lugt, 2002). The ultrastructural findings in the brain of sheep in this study indicate that intramyelinic vacuolation is the case in A. glazioviana poisoning.

The morphology and distribution of the light microscopical changes of status spongiosus observed in sheep of this study are rather similar to those induced 
in the ruminant brain by other poisonous plants such as Helichrysum argyrosphaerum in sheep and goats, Ornithogalum saundersiae and $O$. prasinum in cattle and chemicals such as the antiparasitics closantel and rafoxanide in sheep and goats (VAN DER LUGT, 2002). Cerebral spongy degeneration in ruminants has also been described as a condition secondary to chronic and diffuse liver disease (hepatic encephalopathy) from several causes, such as Senecio spp. (BARROS et al., 1992) and Crotalaria spp. (VAN DER LUGT, 2002) poisoning in cattle and chronic copper toxicosis in sheep (ILHA et al., 2001).

It is interesting to note that myocardial lesions and the cerebral spongy degeneration similar to the ones found in sheep of this study and to the ones described in adult sheep and cattle with spontaneous A. glazioviana poisoning, were reproduced in the fetuses of pregnant ewes experimentally fed with A. glazioviana (RAFFI et al., 2004) and are considered to be responsible for death of the fetus and abortion, stillbirth or deliverance of weak lambs that die soon after birth. The active principle of A. glazioviana remains undetermined.

\section{ACKNOWLEDGEMENTS}

Part of Doctoral Thesis of the first author. The authors are grateful to Prof. Severo S. de Barros for the ultrastructure studies performed in the material of this study.

\section{REFERENCES}

BARROS, C.S.L. et al. Senecio spp. poisoning in cattle in southern Brazil. Veterinary and Human Toxicology, v.34, p.241-246, 1992.

GAVA, A.; BARROS, C.S.L. Field observations of Ateleia glazioviana poisoning in cattle in southern Brazil. Veterinary and Human Toxicology, v.43, p.37-41, 2001.
GAVA, D. et al. Intoxicação espontânea por Ateleia glazioviana (Leg. Papilionoideae) em ovinos. In: ENCONTRO NACIONAL DE PATOLOGIA VETERINÁRIA, 11., 2003, Botucatu, SP. Anais... Botucatu, 2003. V.11, 297p. p.60.

ILHA, M.R.S. et al. Intoxicação espontânea por Senecio brasiliensis (Asteraceae) em ovinos. Pesquisa Veterinária Brasileira, v.21, p.123-138, 2001.

KELLERMAN, T.S. et al. Heart. In: Plant poisoning and mycotoxicoses of Livestock in South Africa. Cape Town: Oxford University, 1988. Cap.3, p.83130 .

LEITE, L.G. et al. Susceptibilidade de animais de laboratório à intoxicação por Ateleia glazioviana (Leg. Papilionoideae). Pesquisa Veterinária Brasileira, v.22, p.73-78, 2002.

PEIXOTO, P.V. et al. Doença do peito inchado, Tetrapterys spp poisoning, brisket disease and St. George disease: A comparative study. Pesquisa Veterinária Brasileira, v.15, p.43-50, 1995.

RAFFI, M.B. et al. The pathogenesis of reproductive failure induced in sheep by the ingestion of Ateleia glazioviana. Veterinary and Human Toxicology, v.46, p.233-238, 2004.

ROBINSON, W.F.; MAXIE, M.G. The cardiovascular system. In: JUBB K.V.F. et al. (Eds). Pathology of domestic animals. 4.ed. San Diego: Academic, 1993. V.3, cap.1, p.1-100.

STIGGER, A.L. et al. Intoxicação experimental por Ateleia glazioviana (Leg. Papillionoidea) em ovinos. Pesquisa Veterinária Brasileira, v.21, p.98-108, 2001.

VAN DER LUGT, J.J. The clinicopathology and pathology of selective toxicoses and storage diseases of the nervous system of ruminants in Southern Africa. 2002. $174 \mathrm{f}$. Tese (Doutorado em Patologia Veterinária) - University of Utrecht, The Netherlands. 